\title{
The future of Englishes
}

\author{
DAVID CRYSTAL
}

\author{
Does an increasing awareness of the sheer \\ international variety in the English language complex \\ necessitate a new pedagogy for a new century?
}

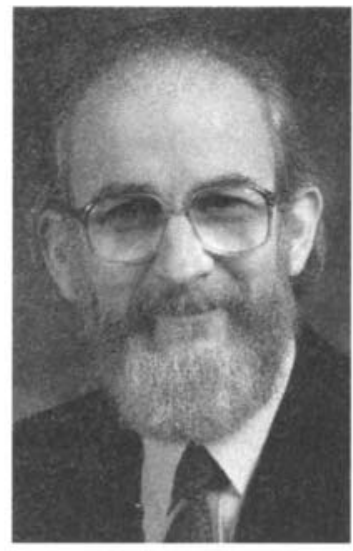

[The following article is a slightly adapted version of a paper given to the British Council Conference 'Innovation and Best Practice in British ELT', at Oxford, July 1998.]

THE PACE is hotting up. Reluctant as I have been to be swayed by the fashionable neologizing of recent years, my title shows capitulation. Like many since the early 1970s I have become used to the steady pluralization of the noun English, in such phrases as 'new Englishes' or the journal title 'World Englishes'. Associated locutions, such as 'an English' and 'each English' are also now routine. 'The English languages' is a phrase which has been used for over a decade, most recently by Tom McArthur as the title of his book for Cambridge University
Press's Canto series (1998). 'Is English Really a Family of Languages?' was the title of an article in the International Herald Tribune a few years ago (Rosen, 1994). And I have no doubt that we shall soon hear all the jargon of comparative philology turning up in the domain of ELT - daughter languages, sister languages, and the like. The question we all have to face, of course, is how a concept of 'best practice' survives in the face of such massive and unprecedented innovation. This must be part of what the present conference is intending to explore. But such explorations are likely to succeed only if we are clear in our theoretical thinking about what might be going on, and are clear about the facts of language change which motivate that thinking. Both levels of clarity are in short supply, at the moment.

\section{Part 1: Language matters}

\section{Intelligibility and identity}

I begin by exploring the metaphor of 'family" a little. What could an English 'family' of languages possibly mean? The term 'family', of course, arose with reference to such domains as 'Indo-European', 'Romance' and 'Slavic' domains where there exists a clearly identifiable set of entities whose mutual unintelligibility would allow them to be uncontroversially classified as different languages. Intelligibility is the traditional criterion, and when that has been applied to the case of English, there has hitherto been little justification for the notion of an English language family. Although there are several well-known instances of English regional accents and dialects causing problems of intelligibility to people from a different dialect background, especially when encountered at rapid conversational speed - in Britain, Cockney (London), Geordie (Newcastle), Scouse (Liverpool) and Glaswegian (Glasgow) are among the most commonly cited cases the problems largely resolve when the speaker slows down, or they reduce to difficulties over isolated lexical items. This makes regional vari- 
eties of English no more problematic for linguistic theory than, say, occupational varieties such as legal or scientific. It is no more illuminating to call Cockney or Scouse 'different English languages' than it would be to call Legal or Scientific by such a name, and anyone who chooses to extend the application of the term 'language' in this way finds a slippery slope which eventually leads to the blurring of the potentially useful distinctions between 'language', 'variety', and 'dialect'.

The intelligibility criterion has traditionally provided little support for an English language family (whether it will continue to do so I shall discuss below). But we have learned from sociolinguistics in recent decades that this criterion is by no means an adequate explanation for the language nomenclature of the world, as it leaves out of consideration linguistic attitudes, and in particular the criterion of identity. If intelligibility were the only criterion, then we would have to say that people from Norway, Sweden and Denmark spoke a single language - 'Scandinavian', perhaps - with several regional varieties. The socio-political history of these nations, of course, disallows any such option. Swedes speak Swedish, Norwegians Norwegian, and Danes Danish - or at least (as a Dane glumly remarked to me the other day), they do when they are not speaking English. Or, to take a more recent example of how language nomenclature can change (and rapidly): at the beginning of the $1990 \mathrm{~s}$, the populations of Croatia, Bosnia, and Serbia would all be described as speaking varieties of Serbo-Croatian. Today, the situation has polarized, with Croatians considering the language they speak to be Croatian, and Serbs Serbian, and efforts being made to maximise the regional differences between them. The 'Croatian variety of Serbo-Croatian' has become 'the Croatian

DAVID CRYSTAL read English at University College London, and has held posts in linguistics at the University College of North Wales, Bangor, and at the University of Reading, where he taught for twenty years. He works currently as a writer, lecturer, and broadcaster on language and linguistics. Among his publications are 'Listen to Your Child', 'Who Cares About English Usage?', 'The Cambridge Encyclopedia of Language', 'The Cambridge Encyclopedia', 'The Cambridge Encyclopedia of the English Language', 'English as a Global Language', and 'Language Play' (see p.21). language'. A similar story can be found in any part of the world where language is an emergent index of socio-political identity.

That is the point: if a community wishes its way of speaking to be considered a 'language', and if they have the political power to support their decision, who would be able to stop them doing so? The present-day ethos is to allow communities to deal with their own internal policies themselves, as long as these are not perceived as being a threat to others. However, to promote an autonomous language policy, two criteria need to be satisfied. The first is to have a community with a single mind about the matter, and the second is to have a community which has enough political-economic clout to make its decision respected by outsiders with whom it is in regular contact. When these criteria are lacking, the movement is doomed.

\section{Ebonics}

An illustration of a movement's failure is the Ebonics controversy in California in 1996. This incident received widespread publicity during December 1996, most reports sharing the content and tone of this New York Times editorial (24 December), under the heading of 'Linguistic Confusion':

The school board in Oakland, Calif., blundered badly last week when it declared that black slang is a distinct language that warrants a place of respect in the classroom. The new policy is intended to help teach standard English and other subjects by building on the street language actually used by many innercity children and their parents. It is also designed to boost self-esteem for underachievers. But by labeling them linguistic foreigners in their own country, the new policy will actually stigmatize African-American children - while validating habits of speech that bar them from the cultural mainstream and decent jobs.

The name Ebonics - a blend of Ebony + phonics - was being given to the variety of English spoken by African Americans, which had previously been called by such names as Black Vernacular English or African-American Vernacular English. Although the intentions behind the move were noble, it was denounced by people from across the political and ethnic spectrum, including such prominent individuals as Education Secretary Richard W. Riley, the black civil rights leader Rev. Jesse Jackson, and 
writer Maya Angelou. Quite evidently the two criteria above did not obtain: the US black community did not have a single mind about the matter - indeed they seemed largely to oppose the suggestion, for such reasons as were mentioned in the Times editorial - and the people who had the political-economic clout to make the decision respected were also against it. The school board withdrew its proposal a month later.

\section{Scots}

By giving a distinct name, Ebonics, to what had previously been uncontroversially recognized as a variety of English, a hidden boundary in the collective unconscious seems to have been crossed. It is in fact very unusual to assign a novel name to a variety of English in this way, other than in the humorous literature, where such names as Strine (a spelling of an imagined casual Australian pronunciation of the word 'Australian') can be found. With just one exception, within Britain and America, there has never been a situation where a specific regional variety of English has acquired a new name as part of its claim to be recognized as a standard in its locality. That exception is Scots. Here is McArthur's summary of the situation (1998: 138):

The people of Scotland occupy a unique historical and cultural position in the Englishspeaking world. They use the standard language (with distinctive phonological, grammatical, lexical, and idiomatic features) in administration, law, education, the media, all national institutions, and by and large in their dealings with Anglophones elsewhere, but in their everyday lives a majority of them mix 'the King's English' with what in an earlier age was called 'the King's Scots'.

What would Scots look like, if it were written down? A little later in the chapter (p. 149), McArthur tells the story of a time when he was filling in an annual form which asked him to state his modern language skills. The first few times he wrote 'English' and 'French'; then, as he says, having 'grown a touch mutinous', he added 'Scots' (he is from Glasgow). He adds:

Nobody commented on the change; perhaps nobody noticed it. But fur masel, Ah'd cróssit a wee bit Rubicon aa ón ma lain - an, efter aa the years that separatit ma faither an me, Ah stertit tae feel a gey wheen shairer aboot ma ain owrelookit mither tongue.
[My translation: But for myself, I'd crossed a little bit [of] Rubicon all on my own - and, after all the years that separated my father and me, I started to feel a considerable amount surer about my own overlooked mother tongue.]

How does Scots stand in relation to the two criteria referred to above? The situation is unclear, because the Scots community does not have a single mind about the matter, nor has it had enough political-economic clout to make any decision respected by outsiders. In relation to the former point, the case in favour has been strongly argued by the leading scholar on Scots, the late Jack Aitken. After reviewing the arguments, he concluded (1985: 44):
All the phenomena just recounted - the distinctiveness of Scots, its still substantial presence in daily speech, the fact that it was once the national language, its identifiably distinct history, its adoption (some Gaels would call it usurpation) of the nation's name, and the massive and remarkable and still vital literature in it, mutually support one another and one further and remarkable phenomenon - the ancient and still persistent notion that Scots is indeed 'the Scottish language'.

But the missionary tone of this quotation, along with the indication that at least one section of the Scottish community thinks differently, suggests a complex sociolinguistic situation; and at the end of his article even Aitken pulled back from the brink:
I believe what I have written suggests that if Scots is not now a full 'language' it is something more than a mere 'dialect'. A distinguished German scholar once called it a Halbsprache - a semi-language.

In relation to the second criterion, it remains to be seen whether the changing political situation in Scotland (the 1997 referendum on devolution agreeing the formation of a new Scots Assembly) will produce a stronger voice in favour of Scots. McArthur is doubtful (ibid.):
Any political change in the condition of Scotland is unlikely to have a direct influence on the shaky condition of Scots or Gaelic, because the movement for Scottish autonomy (within the EU) does not have a linguistic dimension to it.

If he is right, then that eliminates the strongest traditional contender for a separate identity within an English 'family of languages'. 


\section{The changing situation}

But new contenders are entering the ring - an inevitable consequence of the emergence of English as a genuine global language. 'Genuine' is used here in order to reflect the reality that English is now spoken by more people (as a first, second, or foreign language) than any other language and is recognized by more countries as a desirable lingua franca than any other language. This is not the place to recapitulate the relevant statistics, insofar as they can be established: this information is available elsewhere (for my own estimates, see Crystal, 1995, 1997; see also Graddol, 1998). But it is important to recognize that the unprecedented scale of the growth in usage (approaching a quarter of the world's population) has resulted in an unprecedented growth in regional varieties.

Variation, of course, has always been part of the language, given that Angles, Saxons, and Jutes must have spoken different Germanic dialects. The emergence of Scots can be traced back to the beginning of the Middle English period. In the 18th century, Noah Webster was one of many who argued the need to recognize a distinct American (as opposed to British) tongue. And the issue of identity has been central to debate about the nature of creole and pidgin Englishes around the world. But it is only in recent decades (chiefly, since the independence era of the 1960s) that the diversity has become so dramatic, generating a huge literature on 'world Englishes' and raising the question of linguistic identity in fresh and intriguing ways.

\section{Hybrids}

The chief aim of McArthur's book is to draw attention to the remarkable 'messiness' which characterizes the current world English situation, especially in second language contexts. Typically, a 'new English' is not a homogeneous entity, with clear-cut boundaries, and an easily definable phonology, grammar, and lexicon. On the contrary, communities which are putting English to use are doing so in several different ways. As McArthur puts it (p. 2), 'stability and flux go side by side, centripetal and centrifugal forces operating at one and the same time'. And when actual examples of language in use are analysed, in such multilingual settings as Malaysia and Singapore, all kinds of unusual hybrids come to light.
Different degrees of language mixing are apparent: at one extreme, a sentence might be used which is indistinguishable from standard English. At the other extreme a sentence might use so many words and constructions from a contact language that it becomes unintelligible to those outside a particular community. In between, there are varying degrees of hybridization, ranging from the use of a single lexical borrowing within a sentence to several borrowings, and from the addition of a single borrowed syntactic construction (such as a tag question) to a reworking of an entire sentence structure. In addition, of course, the pronunciation shows similar degrees of variation, from a standard British or American accent to an accent which diverges widely from such standards both in segmental and nonsegmental (intonational, rhythmical) ways (Crystal, 1996).

For example, within a few lines from less than half-a-minute of Malaysian conversation, we can extract the following utterances (for the original conversation, see Baskaran, 1994). At the top of the list is a sentence which could be called Standard Colloquial English; below it are other sentences which show increasing degrees of departure from this norm, grammatically and lexically. At the bottom is a sentence (in this English dialogue) which is entirely Colloquial Malay.

Standard colloquial English

Might as well go window-shopping a bit, at least.

Grammatical hybrids

My case going to be adjourned anyway. [auxiliary verb omitted]

Okay, okay, at about twelve, can or not? [distinctive tag question in English]

You were saying you wanted to go shopping, nak perga tak? [addition and tag question in Malay 'Want to go, not?']

Can lah, no problem one! ['I can'; lah is an emphatic particle]

\section{Lexical hybrids}

No chance to ronda otherwise. [Malay 'loaf]

You were saying, that day, you wanted to beli some barang-barang. [Malay 'buy ... things']

But if anything to do with their stuff - golf or snooker or whatever, then dia pun boleh sabar one. [Malay 'he too can be patient']

Colloquial Malay

Betul juga. ['True also']

Continua of this kind have long been recognized in creole language studies. What is novel, as McArthur points out, is the way phenomena 
of this kind have become so widespread, happening simultaneously in communities all over the world. After reviewing several speech situations, he concludes (p. 22):

Worldwide communication centres on Standard English, which however radiates out into many kinds of English and many other languages, producing clarity here, confusion there, and novelties and nonsenses everywhere. The result can be - often is - chaotic, but despite the blurred edges, this latter-day Babel manages to work.

\section{Outlandish English}

I imagine there would have been a similar sense of chaos during the periods of rapid change in English language history, notably the early Middle Ages and the Renaissance. The arrival of thousands of words and expressions from French, for example, would not have passed without comment. Indeed, we do occasionally find such a comment. There is the famous 'egg' story of Caxton (Prologue to Virgil's Book of Eneydos, c.1490), for instance (I have modernized the morphology, spelling and punctuation, apart from the two critical words: for the original, see the text in Crystal, 1995: 57):

And certainly our language now used varies far from that which was used and spoken when I was born. For we English men are born under the domination of the moon, which is never steadfast but ever wavering, waxing one season and waning and decreasing another season. And that common English that is spoken in one shire varies from another. In so much that in my days [it] happened that certain merchants were in a ship in Thames for to have sailed over the sea into Zealand, and for lack of wind they tarried at the Foreland and went to land for to refresh them. And one of them named Sheffield, a mercer, came into a house and asked for meat, and specially he asked after eggys. And the good wife answered that she could speak no French. And the merchant was angry, for he also could speak no French, but would have had egges, and she understood him not. And then at last another said that he would have eyren. Then the good wife said that she understood him well. Lo! What should a man in these days now write, egges or eyren? Certainly it is hard to please every man by cause of diversity and change of language.

Egges was a northern form, a development from Old Norse. Eyren was a southern form, a development from Old English. French has nothing to do with it - but the fact that the story is reported in terms of French clearly suggests the extent to which there was pressure on the contemporary consciousness.

As a second example, there is the comment of 16th-century scholar Thomas Wilson, in The Arte of Rhetorique (1553), objecting to the 'inkhorn terms' (i.e. learned terms) that were being widely introduced into English at the time (again, spelling and punctuation have been modernized).

Some seek so far for outlandish English that they forget altogether their mother's language. And I dare swear this, if some of their mothers were alive, they were not able to tell what they say; and yet these fine English clerks will say they speak in their mother tongue, if a man should charge them with counterfeiting the King's English.

'Certainly it is hard to please every man by cause of diversity and change of language'? 'Counterfeiting the King's English'? Hybridization has been a feature of English since AngloSaxon times. Any history of English shows that the language has always been something of a 'vacuum-cleaner', sucking in words and expressions from the other languages with which it has come into contact. (This point has often been neglected by countries who complain these days about the extent to which they have been affected by 'Anglicization'. English has been 'Frenchified' in the past far more than French has recently been 'Anglicized'.) But today, with more contact being made with other languages than ever before, the scale of the borrowing is much greater than it has been in the past. A wider range of languages is involved: there are over $\mathbf{3 5 0}$ modern languages listed in the etymology files of the Oxford English Dictionary. And the borrowing is now found in all varieties of English, and not just in the more academic or professional domains.

\section{Novel developments}

Moreover, we have by no means exhausted the novel kinds of hybrid which linguistic change has in store for us. Consider, for example, the situation which is appearing with increasing frequency around the world in regions where there are high immigration or 'guestworker' populations. A man and a woman from different first-language backgrounds meet, fall in love, and get married, using the English they 
learned as a foreign or second language as their only lingua franca. They then have a baby, who learns from them - what, exactly? The child will hear English as a foreign language from its parents, but will learn this as its mother tongue. What form will this take? Will there be a linguistic growth analogous to that which takes place when a pidgin becomes a creole though beginning, one imagines, at a much more advanced level of structural development? What kind of English will be the outcome? We are faced with the notion of foreignlanguage (or second-language) English as a mother tongue. Our nice models of World English - for example, in terms of concentric circles - will need some radical overhaul to cope with this.

Or, to take another example: the corridors of power in such multinational settings as Brussels. Although several languages are co-official in the European Union, pragmatic linguistic realities result in English being the most widely used language in these corridors. But what kind of common English emerges, when Germans, French, Greeks, and others come into contact, each using English with its own pattern of interference from the mother tongue? There will be the usual sociolinguistic accommodation, and the result will be a novel variety of 'Euro-English' - a term which has been used for over a decade with reference to the distinctive vocabulary of the Union (with its Eurofighters, Eurodollars, Eurosceptics, and so on: for a few recent examples using the Europrefix, see Knowles (1997); for earlier examples, Mort (1986)), but which must now be extended to include the various hybrid accents, grammatical constructions, and discourse patterns encountered there.

On several occasions, English-as-a-firstlanguage politicians, diplomats, and civil servants working in Brussels have told me how they have felt their own English being pulled in the direction of these foreign-language patterns. A common feature, evidently, is to accommodate to an increasingly syllable-timed rhythm. Others include the use of simplified sentence constructions, and the avoidance of idioms and colloquial vocabulary, a slower rate of speech, and the use of clearer patterns of articulation (avoiding some of the assimilations and elisions which would be natural in a first-language setting). It is important to stress that this is not the 'foreigner talk' reported in an earlier ELT era. My British informants (I have no information on what their US counterparts do) were not 'talking down' to their colleagues, or consciously adopting simpler expressions: this was unconscious accommodation, which they were able to reflect upon only after considerable probing on my part.

\section{WSPE and WSSE}

A philosophy of diversity, recognizing the importance of hybridization, does not exclude the notion of a standard, of course. This is a point which the oversimplifying prescriptive pundits of the world consistently get wrong: in honeyed tones, they think that a focus on diversity must mean a dismissing of standards. On the contrary: the need to maintain international intelligibility demands the recognition of a standard variety of English, at the same time as the need to maintain local identity demands the recognition of local varieties of English. My fundamental principle is that we need both, in a linguistically healthy world. And our theoretical as well as pedagogical models need to allow for the complementarity of these two functions of language.

There are two complications which we need to anticipate. First, the emergence of new varieties is very likely going to increase the pace of change in what counts as standard usage. It would be surprising if, at least at a spoken level, the trends which we see taking place simultaneously all over the English-speaking world did not at some point merge, like separate drops of oil, to produce an appreciable normative shift. What long-term chance has the tag question got, for example, in its full array of grammatical concord, faced with the simplifying tendencies which can be heard everywhere - and which have their analogues in such first-language contexts as Estuary English (right?) or Anglo-Welsh English (te?). Would you place good euros on the long-term survival of interdental fricatives in standard English, in a world where there will be five times as many English speakers for whom th is a pain as those for whom it is a blessing?

The second complication is that we seem to be moving towards a global situation in which English speakers will have to operate with two levels of spoken standard. This is not something which people have had to cope with before. Standard English, as it currently exists, is a global reality only with reference to the written language: it might more accurately be 
called World Standard Printed English (WSPE). The comparison of international written varieties in The Cambridge Encyclopedia of the English Language (1995: 300ff.) showed WSPE to be pretty well the same wherever it is encountered. This is what one would expect. That is what a standard is for. It would not be able to fulfill its role as an international (written) lingua franca if it were riddled with regional idiosyncrasies. And, apart from a few instances of literature and humour involving the representation of regional dialect, and the occasional US/UK spelling variation, WSPE has no regional manifestations.

But if a spoken equivalent to WSPE develops - World Standard Spoken English (WSSE), as I have elsewhere called it (Crystal, 1997), a regionally neutral international spoken standard, acting as a stabilizing force on global spoken diversity - this situation will change. I have drawn attention to its emergence elsewhere (Crystal 1998), having encountered international gatherings where people are using English as their spoken lingua franca, while trying to avoid the idiosyncrasies associated with national varieties of expression. At one international seminar, for example, a casual use of a baseball idiom (out in left field) by an American led to the temporary disruption of the meeting (as non-Americans debated what it meant) and resulted in the selfconscious side-stepping of further regional expressions by all the participants. It might not have gone that way, of course. On another occasion, the participants might have decided to adopt the US idiom - using it back to the American, and by definition - turning what was an Americanism into a global usage. That has been the predominant practice in the past. Whether WSSE will prove to be predominantly American in its historical origins, in the long term, or whether other varieties from around the world will 'gang up' on American English, swamping it by weight of numbers, is currently unclear. But some sort of WSSE, I have no doubt, will emerge.

\section{An international norm}

Whatever the eventual character of WSSE, it will occupy a world which, as far as its use of English as a spoken lingua franca is concerned, will be a multidialectal one. Many of us will have three dialects at our disposal, and - unlike the WSPE situation - two of these will have sta- tus as educated standards. Using myself as an example, I already have my original Welsh/Scouse mix functioning as a marker of local identity, and my educated (Standard) British English functioning both as a means of national communication within Britain and as a marker of national identity outside. The scenario I have outlined suggests that one day there will additionally be an international standard of spoken English, to be used as a means of international communication in an increasingly diversified world (as well as, possibly, a marker of Earthly identity, once we have a community presence on other planets). In further due course, the different kinds of standard may evolve their written equivalents, and we will end up with two educated standards in writing as well. To call this situation a kind of diglossia (or triglossia) is probably not too misleading, although the kind of functional distinctions involved are not really the same as the 'High' vs 'Low' functionality seen in the case of such languages as Greek or Arabic. It anticipates a day when learners will have to adapt their British Standard English to an international norm - or perhaps vice versa, learning an international norm first, and modifying it to British (or US, etc.) English. The situation may not be unlike the kinds of shift which learners have to make these days when they visit Britain, and find that the Standard British English they have been taught needs adaptation if it is to work to best effect in, say, Scotland or in Wales. But a world in which there are two educated standards of spoken English seems inevitable.

\section{Part 2: Teaching matters}

MUCH of the evidence presented in this paper is anecdotal. It can do little more than provide motivation for hypotheses. There is a real need for empirical research into these hybrid language situations. But it is plain that the emergence of hybrid trends and varieties raises all kinds of theoretical and pedagogical questions:

- They blur the long-standing distinctions between 'first', 'second', and 'foreign' language. - They make us reconsider the notion of 'standard', especially when we find such hybrids being used confidently and fluently by groups 
of people who have education and influence in their own regional setting.

- They present the traditionally clear-cut notion of 'translation' with all kinds of fresh problems, for (to go back to the Malaysian example) at what point in a conversation should we say that a notion of translation is relevant, as we move from 'understanding' to 'understanding most of the utterance precisely' to 'understanding little of the utterance precisely ("getting the drift" or "gist")' to 'understanding none of the utterance, despite its containing several features of English'?

- And, to move into the sociolinguistic dimension, hybrids give us new challenges in relation to language attitudes: for example, at what point would our insistence on the need for translation cause an adverse reaction from the participants, who might maintain they are 'speaking English', even though we cannot understand them?

This is the Caxton situation again.

\section{Towards a new pedagogy}

'O brave new world, That has such people in't'. Miranda's exclamation (from The Tempest, V. i. 88 ) is apposite. It is a brave new world, indeed; and those who have to be bravest of all are the teachers of English. I am never sure whether to call language teaching or translating the most difficult of all the language tasks; both are undeniably highly demanding and professional activities (and it is one of the world's greatest scandals that such professions can be so badly paid). But in a world where traditional models and values are changing so rapidly, the task facing the teacher, in particular, is immense. Keeping abreast of all that is taking place is a nightmare in itself. Deciding what to teach, given the proliferation of new and competing models, requires metaphors which go beyond nightmares. Is there any consensus emerging about what a teacher should do, in such circumstances?

My impression, as I travel around and listen to people reporting on their experiences, is that this situation - one of rapid linguistic transition - is demanding an increased recognition of the fundamental importance of distinguishing between production and reception skills in language teaching.

From a production point of view, there is a strong case for pedagogical conservatism. If one is used to teaching standard English and an
$\mathrm{RP}$ accent, this argument goes, then one should continue to do so, for a whole range of familiar reasons - the linguistic knowledge base is there in the various analyses and descriptions, there are copious course-books and materials, and there is a well understood correspondence between the norms of spoken and written expression (important for examination purposes as well as for reading literature). In short, there is a general familiarity with this variety which must breed a modicum of content.

But from the viewpoint of listening comprehension, there is an equally strong case for pedagogical innovation. It is a fact that RP is changing (to be precise, continuing to change), and that many forms of 'regionally modified $\mathrm{RP}$ ' are now to be heard among educated people in Britain and abroad. It is a fact that several regional accents (e.g. Edinburgh Scots, Yorkshire) are now more prestigious than they used to be, and are being used in settings which would have been inconceivable 20 years ago such as by presenters on radio and television, or by switchboard operators in the rapidly growing domain of telemarketing, or for that matter by keynote lecturers at British Council conferences. It is a fact that new regional firstlanguage standards, in dialect as well as accent, are emerging in such countries as Australia and South Africa.

It is a fact that new regional secondlanguage standards are emerging in such areas as West Africa and the subcontinent of India though less obvious how far these are countryrestricted: see Crystal (1995: 358ff.). And it is a fact that there are new hybrids emerging in foreign-language contexts all over the Englishspeaking world.

\section{Flexibility and variety}

If this is the case, teachers need to prepare their students for a world of staggering linguistic diversity. Somehow, they need to expose them to as many varieties of English as possible, especially those which they are most likely to encounter in their own locale. And above all, teachers need to develop a truly flexible attitude towards principles of usage. The absolutist concept of 'proper English' or 'correct English', which is so widespread, needs to be replaced by relativistic models in which literary and educated norms are seen to maintain their place alongside other norms, some of which 
depart radically from what was once recognized as 'correct'.

Yes, familiarity breeds content - but also contempt, when it fails to keep pace with social realities. All over the world there are people losing patience with what they perceive to be an irrational traditionalism. You will all have your own stories of the uncertainties and embarrassments generated when accepted local usages come into conflict with traditional standards. While there are still some parts of the world where there is a reverential attitude towards British English in general, and RP in particular, this attitude is rapidly being replaced by a dynamic pragmatism. If people in a country increasingly observe their own highranking, highly educated people using hybrid forms, if they increasingly hear linguistic diversity on the World Service of the BBC and other channels, if they find themselves being taught by mother-tongue speakers who themselves reflect current trends in their regionally tinged speech, then who can blame them if they begin to be critical of teaching perspectives which reflect nothing but a parochial past?

\section{The new reality}

Britain leads the world in ELT. I believe this, and over the past 35 years, since my first close encounter with the British Council, I have repeatedly seen the effective role of that organization in fostering language-teaching methodology. But no-one was predicting such world language scenarios for English in the 1960s. And the biggest challenge facing British ELT in the millennium, and thus the Council at least in its linguistic persona - is how to come to terms with the new global situation. And the future I see for British English Language Teaching requires a reanalysis of the phrase: it must not be $\mathrm{BE}(\mathrm{LT})$; it has to be $\mathrm{B}(\mathrm{EL}) \mathrm{T}$.

The emphasis has got to move away from 'British English' or, at least, to a revised concept of British English which has variety at the core. For what is British English today? The spoken British English of Britain is already a mass of hybrid forms, with Celtic and immigrant language backgrounds a major presence. Accent variation is always the clearest index of diversity, because it is a symbol of identity: What we might call 'classical' RP (as described by Gimson, et al) is probably down to about $2 \%$ of the population now; and modified forms of
$\mathrm{RP}$ are increasingly the norm, and regional accents, as we have seen, are increasingly accepted in educated contexts which would have rejected them a generation ago.

If you want to hear good classical RP spoken by whole communities, you will more likely find it in Moscow or Copenhagen than in Manchester or Reading. In Britain itself, diversity is the reality. 'Real Britannia: What Does it Mean to be British?' shouts a headline in The Independent earlier this week, and the author Suzanne Moore comments, towards the end of a piece in which 'a nation in search of an identity' is the theme:

The question, then, is how do we create a modern version of Britishness that is inclusive rather than exclusive, that is based in the present rather than in the past, that is urban rather than rural, that is genuinely multicultural, that does not reside in 'middle England' but amongst a society of hybrids and mongrels.

\section{Linguistic diversity and language health}

Our linguistic past has been shaped by recognizing the value of linguistic diversity; and I believe the same should be true for our linguistic future. ELT policy-making, accordingly, should make diversity its central principle removing it from the periphery to which it has hitherto largely been assigned. No country has dared do this yet. It would be another first for British ELT if we did so. But to do so may make many feel uncomfortable. Could the British Council ever stand up and say, openly, 'There is nothing wrong with teaching American and other varieties of English'? One wonders what might happen to its grant-in-aid if it did!

Even a statement recognizing the value of competing linguistic standards is too much for some. I was a member of the panel which discussed English language issues at the Council's launch of David Graddol's book The Future of English? earlier this year [1998], and I hinted at this view in a contribution I made there. Afterwards, at the buffet, someone came up and asked me if my notion of linguistic tolerance of English diversity extended to such things as the errors foreigners made. I said it all depended on what you mean by an error. $I \mathrm{am}$ knowing, for example, is not allowed in traditional standard English, but it is normal in some parts of the world, such as the Indian sub- 
continent (and also, incidentally, in some British dialects). Would you correct a Frenchman who said I am knowing, then, he asked? It all depends, I said. Not if he was learning Indian English. My interlocutor's face told me that the concept of a Frenchman wanting to learn Indian English was, at the very least, novel.

There was a pause. Then he said, 'Are you saying that, in the British Council, we should be letting our teachers teach Indian English, and not British English?'

'If the occasion warranted it, yes,' I said.

'I don't like the sound of that,' he said, and he literally fled from me, upsetting a glass of wine in the process. He didn't hear me add: 'Or even other languages.'

For in some parts of the world, the wisest advice would be to recommend that we divert some of our resources to maintaining the life of minority languages. Identity and intelligibility are both needed for a healthy linguistic life. And the responsibility of doing something to try to minimize the ongoing damage to the world's ecolinguistic environment - with a language dying somewhere in the world, on average, every fortnight or so - belongs to everyone, whether they are ELT specialists or not.

\section{A change in mindset}

There is indeed a radical change of mindset here. To go back to the example of RP. Even abroad, the many cases of successfully acquired RP - where the influence of the mother-tongue is negligibly present in a person's speech - are far outnumbered, these days, by the cases where the RP is being filtered through an overlay of local segmental phonology and syllable-timed prosody.

This overlay, as we all know, can be so dominant that it can make a person's speech unintelligible to outsiders. And here we face the crux of the matter. If we observe a group of well-educated people from Ghana, or India, or Japan, talking happily together in their country in English, and we find we can understand little of it, what are we to say? Are we to blame the teaching methods, the educational system, the motivation of the learners? Do we continue trying to make their speech improve towards the standard British model (or US, or Australian, or whatever model we are using)? Or do we recognize the possibility that here we may have a new variety of English which has achieved some viability. If this happened in Britain - we arrive in a Glasgow pub, shall we say, and find we are unable to follow the speech of a group at the next table - do we turn to them with a beatific ELT smile, and ask them to speak more clearly? We all know what is likely to happen. The acronym BELT now has a different force.

The assumption, of course, is that if my Glaswegian group were to achieve higher levels of education, their speech would in the process become more diglossic - they would acquire a more standard kind of spoken English, alongside their original dialect. But in the Ghanaian type of case, the higher levels of education are already present in the speakers. Any motivation to change must therefore come from their felt need to make themselves understood to outsiders: If - to put it succinctly - they need us more than we need them, then there is such a motivation - and this has traditionally been the case, with the centre of economic and political power lying outside their country.

But we know from the predictions of David Graddol and others that power centres are ever-changing - and in 50 years time, who knows whether we will not want them more than they want us? In which case, maybe we will have to take pains to accommodate to their dialect (or, of course, language), if we want to make inroads into their markets. It will never be a simple question of code-switching - I chose the word 'accommodation' carefully. There will, I imagine, be give and take on both sides. Trade - whether in products or ideas - is a double-sided notion. But we need to begin now thinking about how such scenarios of mutual respect would relate to our current teaching models and policies. At present I do not think they do at all. I am quite sure that most people still feel that, in the Ghanaian-type case, there is blame to be assigned; that the teaching has been unsuccessful.

\section{'Best practice' in a new century}

I am aware that this kind of talk is controversial - treasonable, probably. Perhaps I am already staking my claim to being the shortest-serving member of the Board in British Council history. I hope not. For we have to address these issues. They will not go away. We cannot stick our heads into the sand, and pretend they are not there. Nor are we alone in having to address 
them. Everywhere else is in the same boat. Or, to be more accurate, they are all in their own boats, each taking on board the waters of diversification and hybridization at its own rate.

American English, with over 350 significant foreign language inputs (according to the last census), is at a particularly waterlogged stage, with over a million people now panicking for the US English lifeboat (Crystal, 1997: Ch. 5); the last decade has seen unprecedented amounts of water slopping into the Australian English boat; and other first-language areas are beginning to find the waters choppy. So indeed are second-language areas. There is no longer (if there ever was) a nice, neat variety called Singapore English. The only reason we ever got the opposite impression is that, when linguists first began to describe these new Englishes, they were working with individual informants, and their descriptions inevitably presented a monolithic picture. As the linguistic viewpoint widens, following more empirical research, diversity gradually comes into focus.

In my view, the chief task facing ELT is how to devise pedagogical policies and practices in which the need to maintain an international standard of intelligibility, in both speech and writing, can be made to comfortably exist alongside the need to recognize the importance of international diversity, as a reflection of identity, chiefly in speech and eventually perhaps also in writing.

English (as opposed to French, Spanish, etc.) Language Teaching is in the best position to do this. We have an advantage in that our language has been coping with diversity for centuries. It is difficult to talk about languages as langues (as collective community awarenesses); but the vacuum-cleaner analogy I used earlier gives a hint about one feature of the English language which must somehow be present in the subconscious of each of us - a readiness to assimilate new forms. It is a thousand years since the publication of the first ELT conversation - the Colloquy of Aelfric, in c. 1000 - and already by that stage English had readily borrowed hundreds of words from other languages, chiefly Latin and Norse. This readiness has been with us ever since. It is a readiness which is conspicuously lacking in, say, the modern French langue - at least, as it has developed over the last 200 years. But
English has it strongly - and perhaps this feature has been an element in its global growth. As has often been observed, people who have learned English as a foreign language have been known to comment on the way in which they were helped by the presence in English of words which they already recognized as deriving from their own.

Any move to a new mind-set is never easy, and some will not wish to make it, for old habits die hard. We should perhaps bring to mind the wise words of Igor Stravinsky, in his Poetics of Music (Ch. 5): 'A renewal is fruitful only when it goes hand in hand with tradition'. But there is no doubt in my mind that the concept of 'best practice' for the next century will need to be grounded in a dynamic linguistic relativism, recognizing as axiomatic the notions of variation and change. This is the chief challenge facing ELT specialists as we move into the new millennium, and it is a challenge which, I believe, British ELT - B(EL)T, as I think of it - is in an excellent position to meet.

ET

\section{References}

Aitken, A. J. 1985. 'Is Scots a language?' In ET3, 41-5. Baskaran, Loga. 1994. 'The Malaysian English mosaic.' In ET 37, 27-32.

Crystal, David. 1995. The Cambridge Encyclopedia of the English Language. Cambridge:University Press.

-. 1996. 'The past, present and future of English rhythm.' In M. Vaughan-Rees, Changes in Pronunciation, Summer 1996 Issue of the Newsletter of the IATEFL Pronunciation Special Interest Group, 8-13. Whitstable: IATEFL.

- 1997. English as a Global Language. Cambridge: University Press.

-. 1998. 'The future of English: where unity and diversity meet.' Keynote address to TESOL Arabia, Al Ayn, March.

Graddol, David. 1998. The Future of English. London: The British Council.

Knowles, Elizabeth, ed. 1997. The Oxford Dictionary of New Words. Oxford: University Press.

McArthur, Tom. 1998. The English Languages. Cambridge: University Press.

Moore, Suzanne. 1998. 'Real Britannia: What Does it Mean to be British?' In The Independent (Monday Review), 20 July.

Mort, Simon. ed. 1986. Longman Guardian New Words. London: Longman.

Rosen, Barbara. 1994. 'Is English Really a Family of Languages?'In the International Herald Tribune, 15 October. 